\title{
Regulation of annual variation in heterotrophic bacterial production in the Schelde estuary (SW Netherlands)
}

\author{
Nico K. Goosen*, Pieter van Rijswijk, Jacco Kromkamp, Jan Peene \\ Netherlands Institute of Ecology, Centre for Estuarine and Coastal Ecology, PO Box 140, 4400 AC Yerseke, The Netherlands
}

\begin{abstract}
Heterotrophic bacterioplankton production ( ${ }^{3} \mathrm{H}$-thymidine incorporation rate) and abundance in the surface water of the Schelde estuary (The Netherlands) were studied during an annual cycle in 1991 along the salinity gradient $(0.8$ to 33 psu). Bacterial production and numbers increased from the lower to the upper estuary. This spatial variability of bacterial production was positively correlated with concentrations of dissolved and particulate organic carbon and negatively correlated with the oxygen concentration. On an annual scale the ratio gross bacterial production:net primary production was larger than 1 in the whole estuary and increased from the lower to the upper estuary. This indicates that bacteria processed more carbon than was put into the system by phytoplankton primary production. A comparable situation is found in other estuaries and shows the high degree of heterotrophy of these systems. Despite the high degree of heterotrophy, temporal variation in bacterial production in the lower Schelde estuary was characterised by a spring and summer bloom and was correlated with phytoplankton primary production. This apparent contradiction is explained by rapid uptake of labile algal exudates by bacteria and a subsequent increase of bacterial production rate during and after the phytoplankton bloom. This idea is corroborated by the absence of an increase in dissolved organic carbon during phytoplankton blooms in the lower estuary. Due to an excess of allochthonous organic carbon and nutrients in the upper estuary, temperature was the most important factor in explaining the variability of bacterial production in this region.
\end{abstract}

KEY WORDS: Heterotrophic bacterial production - Organıc carbon P Primary production · Estuary

\section{INTRODUCTION}

Phytoplankton and heterotrophic bacterioplankton mediate the flow of inorganic and organic carbon and nutrients to higher trophic levels (Pomeroy 1974, Azam et al. 1983). In oligotrophic areas a general dependence of bacterial growth on phytoplankton production is suggested (Larsson \& Hagström 1982, Bird \& Kalff 1984) and bacterial production has been estimated to be 10 to $50 \%$ of net primary production (Hagström et al. 1979, Azam et al. 1983, Cole et al. 1988). Production by heterotrophic bacterioplankton in estuaries is often high when compared to the adjacent coastal areas and open sea. The intensive growth of

\footnotetext{
•E-mail: goosen@cemo.nioo.knaw.nl
}

bacteria in estuaries is due to relatively high organic carbon and nutrient concentrations caused by river inputs and discharge of waste. Estimates of heterotrophic bacterial production and phytoplankton primary production in the Delaware estuary (USA) have shown high ratios of bacterial production to primary production up to ratios $>1$ (Hoch \& Kirchman 1993). Weak correlations between bacterial and phytoplankton biomass and/or production have been observed in the Hudson River estuary (USA) (Findlay et al. 1991). In estuarine and marine environments the temperature has been proven to be an important factor affecting bacterial growth, especially during winter (White et al. 1991, Hoch \& Kirchman 1993, Shiah \& Ducklow 1994a, b, 1995).

The study of organic matter production in the Schelde estuary (The Netherlands) has been focussed 
mainly on phytoplankton primary production (Van Spaendonk et al. 1993, Kromkamp \& Peene 1995a, Kromkamp et al. 1995). Due to high turbidity, phytoplankton primary production was shown to be low. Soetaert \& Herman (1995a, b) modelled the nitrogen and carbon flow in the Schelde estuary and found nitrification to be the major process in nitrogen cycling and in autotrophic fixation of carbon in the upper estuary. The role of heterotrophic bacteria in consumption and production of organic matter in the Schelde estuary is not well known. Billen et al. (1988) predicted intensive bacterial growth, by modelling microbial processes, and Soetaert \& Herman (1995b) showed a very high degree of heterotrophy in the Schelde estuary. By in situ measurements Goosen et al. (1995) showed that in spring, bacterial production rates in the Srhelde estuary are among the highest reported for temperate estuaries.

This paper describes the study of heterotrophic bacterial production during an annual cycle in the Schelde estuary and the adjacent part of the river Schelde. The aim of this research was to investigate the dynamics of heterotrophic bacteria and the relation with potential factors (temperature, organic matter, primary production) controlling heterotrophic bacterial production.

\section{STUDY AREA}

The Schelde estuary (Fig. 1) is a turbid, eutrophic estuary in the southwest of The Netherlands (latitude: $51^{\circ} 14^{\prime}$ to $51^{\circ} 26^{\prime} \mathrm{N}$, longitude: $3^{\circ} 35^{\prime}$ to $4^{\circ} 24^{\prime} \mathrm{E}$ ). In the central and lower part of the estuary the tidal channels are separated by intertidal flats. The navigation channel has a depth of 15 to $20 \mathrm{~m}$. The average depths of compartments 1 to 15 (shaded areas in Fig. 1) are 13.7, 12, 9.9, 9, 11.9, 11.9, 6.7, 8, 9, 10.1, $9.7,9.7,10.4,9$, and 9 respectively. The river Schelde, which has a catchment area of $19500 \mathrm{~km}^{2}$ (Heip 1989), is the most important freshwater source. The average discharge of $100 \mathrm{~m}^{3} \mathrm{~s}^{-1}$ is low compared to the tidal exchange of $100000 \mathrm{~m}^{3} \mathrm{~s}^{-1}$ The total volume of the estuary in compartments 1 to 10 is 2.5 billion $\mathrm{m}^{3}$ and the surface area is about $300 \mathrm{~km}^{2}$ The residence time of the water in the estuary is about $75 \mathrm{~d}$ (Heip 1989), causing a gradual salinity gradient of approximately 0.8 psu near the city of Temse (Stn 15) to 29 psu near the coastal city of Vlissingen (Stn 1; Fig. 1). In general the water in the estuary is well mixed with maximum tidal currents of about 1 to $1.5 \mathrm{~m} \mathrm{~s}^{-1}$. The estuary is heavily polluted by domestic and industrial waste, causing intensive bacterial growth (Billen et al. 1988, Goosen et al. 1995). Intense bacterial respiration and the long residence time of the water lead to oxygen depletion and a large efflux

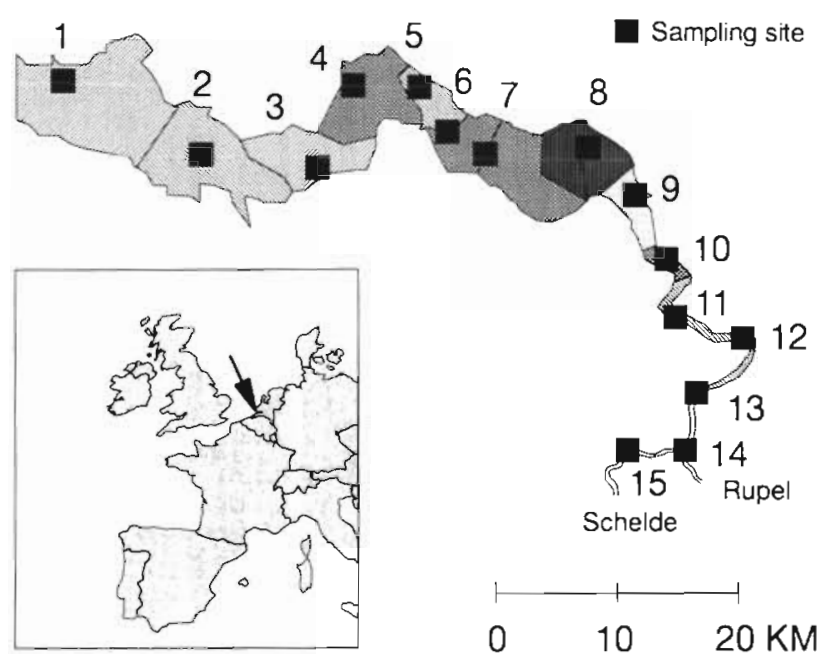

Fig. 1. Map of the Schelde estuary, The Netherlands, with sampling sites. The hatching indicates compartments, represented by the different sampling stations. The morphology of the compartments was used to calculate integral column production

of $\mathrm{CO}_{2}$ to the atmosphere in the central and upper parts of the estuary (Goosen et al. 1995, Frankignoulle et al. 1996). In this low-oxygen zone of the estuary a zone of maximum turbidity is also located. Due to the high turbidity, primary production by phytoplankton in the Schelde estuary has been shown to be light limited (Van Spaendonk et al. 1993) and in the central and upper parts of the estuary no net annual primary production could be calculated (Kromkamp \& Peene $1995 \mathrm{a}$, b). Nutrient concentrations are high, with concentrations of inorganic nitrogen, phosphate and silicate from 70 to 600,3 to 20 and 5 to $230 \mu \mathrm{M}$ respectively (Kromkamp et al. 1995).

\section{METHODS}

Water sampling. In 1991, surface water from 15 stations in the Schelde estuary (Fig 1) was sampled, from the RV 'Luctor', every 2 wk from March to October. For the rest of the year the stations were sampled once a month. During each cruise all stations were sampled within $2 \mathrm{~d}$. At the time of sampling, temperature, $\mathrm{pH}$, oxygen concentration and salinity were measured in situ with a CTD probe ( $\mathrm{H} 2 \mathrm{O}$ datasonde coupled to a Surveyor 3, Hydrolab).

Chemical analyses. Suspended particulate matter (SPM) dry weight was determined gravimetrically on glass fiber filters (GF/C, Whatman) after drying at $70^{\circ} \mathrm{C}$. On the same filters particulate organic carbon (POC) was determined with a nitrogen/carbon analyser (model NA 1500, Carlo Erba) as described by Nieuwenhuize et al. (1994). 
Samples for analyses of dissolved organic carbon (DOC) were filtered through glass fiber filters (Schleicher \& Schuell, no. 6) which were pretreated at $350^{\circ} \mathrm{C}$. DOC was measured with an autoanalyser (Skalar) using UV destruction and photometric detection.

Bacterial numbers and production. Water samples for enumeration of bacteria were preserved with $1.5 \%$ glutaraldehyde (final concentration) and stored at $5^{\circ} \mathrm{C}$. Bacterial numbers were determined by epifluorescence microscopy after staining with 4',6-diamidino-2phenylindole (DAPl) and filtration on black polycarbonate filters (Porter \& Feig 1980).

Heterotrophic bacterial production rates were estimated by measuring the incorporation rate of tritiated thymidine ([methyl ${ }^{3} \mathrm{H}$ )thymidine, 2.92 to $3.18 \mathrm{TBq}$ mmol $^{-1}$, Amersham Ltd) into cold trichloroacetic acid (TCA)-insoluble material (Fuhrman \& Azam 1982). Triplicate samples of $5 \mathrm{ml}$ were incubated ( 45 to $60 \mathrm{~min}$ ) in the dark with $19 \mathrm{nM}$ tritiated thymidine (final concentration) at in situ temperature, on board the RV 'Luctor' immediately after sampling. Thymidine uptake was linear for at least $2 \mathrm{~h}$ and a concentration of $19 \mathrm{nM}$ thymidine saturated thymidine uptake in the highly productive eastern part of the estuary during winter (Fig. 2). To check if $19 \mathrm{nM}$ also saturated thymidine uptake during a highly productive period, the concentration of thymidine in the assay was doubled in March 1991. This did not increase thymidine incorporation, indicating that $19 \mathrm{nM}$ was still saturating thymidine uptake. As bacterial production rates were rather high in March, and saturation was measured in the part of the estuary with the highest organic carbon and SPM concentrations, we assumed $19 \mathrm{nM}$ thymidine to be saturating in the entire estuary and during the entire year. No estimate of isotope dilution was made, but by using a saturating concentration of thymidine we assumed isotope dilution to be constant. Blank incubations were prefixed with $1.5 \%$ formaldehyde (final concentration). At the end of the incubations the incorporation was terminated by adding $1.5 \%$ formaldehyde (final concentration) to the experimental vials. The vials were stored on ice and cold TCA precipitates on $0.2 \mu \mathrm{m}$ pore size cellulose nitrate filters were obtained as described by Ellenbroek \& Cappenberg (1991). Filters were dissolved in Filtercount (Packard) and radioactivity was measured in a Beckman TD5000 LSC. External standardisation was used to correct for quench. From all the triplicate incorporation measurements the average coefficient of variation (CV $=$ standard deviation/mean $\times 100$ ) was $9 \%, 98 \%$ of the measurements had a CV below $25 \%$ and in $71 \%$ of the measurements the CV was below $10 \%$. Thymidine incorporation rates were converted to production rates in terms of cells and carbon by using a thymidine conversion factor of $2.0 \times 10^{18}$ cells produced $\mathrm{mol}^{-1}$ thymidine

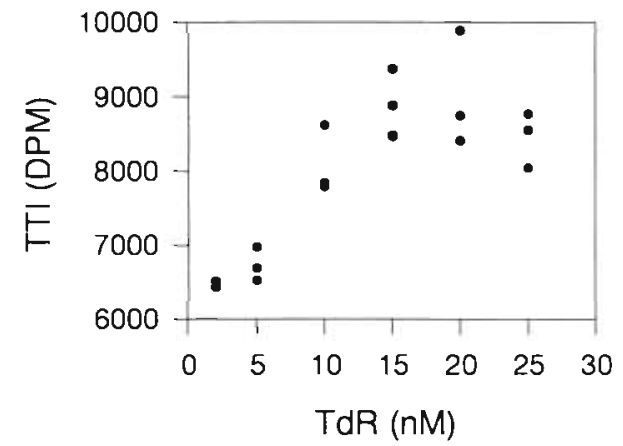

Fig. 2. Trutiated thymidine incorporation (TTI) at increasing concentrations of thymidine (TdR). Measurements were performed in December 1990 in triplicate samples from Stn 10, located in the highly productive turbidity zone of the Schelde estuary. Note that TTl was saturated at $15 \mathrm{nM}$

incorporated (Smits \& Riemann 1988) and a carbon conversion factor of $2.0 \times 10^{-14} \mathrm{~g} \mathrm{C} \mathrm{cell}^{-1}$ (Lee \& Fuhrman 1987). Integral column production was calculated by multiplication of production per volume by the average depth of the corresponding water compartment, indicated by the shaded areas in Fig 1. Annual production was calculated by temporal integration of bacterial production, assuming no diurnal variation and a well mixed water layer at all stations (Goosen et al. 1995).

Primary production. Phytoplankton primary production $\left({ }^{14} \mathrm{C}\right.$ method) and integral column production were measured and calculated according to Kromkamp \& Peene (1995a). Duplicate $50 \mathrm{ml}$ samples [to which $200 \mu \mathrm{l}$ of $925 \mathrm{kBq} \mathrm{ml}{ }^{-1}{ }^{14} \mathrm{C}-\mathrm{NaHCO}_{3}$ (Amersham Ltd) was added] were incubated in a rotating incubator (Vegter \& de Visscher 1984) on board RV 'Luctor' immediately after sampling at in situ temperature. The samples in the incubator were exposed to 10 different irradiances (excluding the dark bottles) up to a maximal irradiance of $810 \mu \mathrm{mol} \mathrm{m} \mathrm{m}^{-2} \mathrm{~s}^{-1}$ After incubation for $2 \mathrm{~h}$ the samples were gently filtered over $0.45 \mathrm{~km}$ pore size nitrocellulose filters. Filters were placed in $\mathrm{HCl}$ fumes for $30 \mathrm{~min}$, air dried and radioactivity was counted in a Beckman TD5000 LSC. Dissolved inorganic carbon was determined by potentiometric titration. Primary production was calculated using an isotope discrimination factor of 1.05. Carbon fixation in the dark bottles was subtracted from that in the light bottles. The photosynthesis/irradiance (P/I) curves were fitted according to Eilers \& Peeters (1988). Water column production was calculated from the fitted P/I curve, the attenuation coefficient and the hourly incident irradiance. Integral column production was calculated by dividing total compartment production, corrected for basin morphology, by the surface area of that compartment.

Statistics. All statistical analyses were performed with Systat (Wilkinson 1989). 


\section{RESULTS}

The annual average salinity in the Schelde estuary varied between 0.8 psu at Stn 15 (Temse) and 29.2 psu at Stn 1 (Vlissingen). Most other physical and chemical factors in the Schelde estuary also showed a longitudinal gradient. The difference in temperature over the salinity gradient was rather small throughout the whole year, range 1.5 to $5.4^{\circ} \mathrm{C}$ with an annual average $( \pm \mathrm{SD})$ of $2.8 \pm 1.0^{\circ} \mathrm{C}$. In the coldest month, February, the temperature of the water was 0.7 and $2.2^{\circ} \mathrm{C}$ at Stns 1 and 15 respectively. During the warmest month, August, temperatures were 20.2 and $22.7^{\circ} \mathrm{C}$ respectively. SPM concentrations increased with decreasing salinity and peaked in the turbidity zone. Due to the gradual salinity gradient no sharp maximum turbidity zone existed in the Schelde estuary but a high turbidity zone was located over a long distance upstream of Stn 8 (Bath). Concentrations of organic carbon, both DOC and POC, also showed an increase with decreasing salinity (Fig. 3A, B). As shown in Fig. 3C, the oxygen concentration showed a sharp decrease with decreasing salinity between Stns 7 and 11. In the marine part of the estuary the water was often supersaturated with oxygen. The low oxygen concentration between Stns 11 and 15 was consistent during the whole year and sometimes the water was completely anoxic.
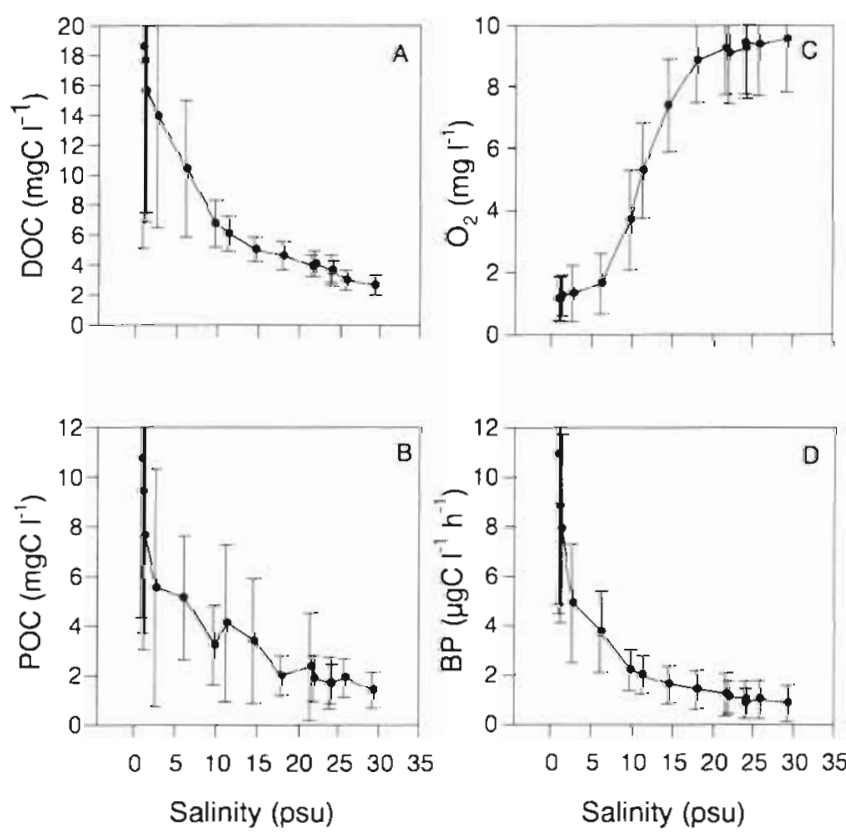

Fig. 3. Annual average $( \pm \mathrm{SD})$ concentrations of $(\mathrm{A})$ dissolved organic carbon (DOC), (B) particulate organic carbon (POC), (C) oxygen, and (D) heterotrophic bacterial production rate (BP) as a function of annual average salinity in the Schelde estuary

\section{Longitudinal profiles of bacterial production}

During the whole year a typical longitudinal profile of heterotrophic baclerial production rate was found along the salinity gradient in the Schelde estuary. Fig. 3D gives the annual average of the bacterial production rate for all stations. From Stn 1 (Vlissingen, average salinity of $29.2 \mathrm{psu}$ ) to Stn 10 (Lillo, average salinity of $9.7 \mathrm{psu}$ ) an almost linear increase of the bacterial production rate with decreasing salinity was found. At lower salinities a more rapid increase of the bacterial production rate was observed with decreasing annual average salinities. Annual average bacterial production rates and organic carbon concentrations showed an almost identical profile (Fig. 3A, B, D). The Spearman rank correlation test showed a strong correlation $\left(r^{2}=0.971\right)$ of the annual average of bacterial production rate with both DOC and POC. Annual average bacterial production rates and oxygen concentrations (Fig. 3C, D) showed a strong inverse correlation $\left(r^{2}=0.981\right)$.

For further analysis of the relation between bacterial production rate and organic carbon concentration over the salinity gradient we analysed all data from separate sampling campaigns (after log-transformation) by linear regression statistics. To eliminate the effect of temperature on the relation between bacterial production and organic carbon, all bacterial production rates were normalised to $15^{\circ} \mathrm{C}$ assuming a $\mathrm{Q}_{10}$ of 2.5 for the thymidine incorporation rate. This $\mathrm{Q}_{10}$ value is close to the value given by Shiah \& Ducklow (1994a). Normalisation of bacterial production for temperature only had a marginal effect on the slope and the intercept of the regression equations. In Fig. 4 the slope of the regression lines of bacterial production versus DOC are given for all sampling dates, During the annual cycle regression analysis for DOC and POC showed comparable patterns of variation. Along the salinity gradient the results of regression analysis between bacterial production and DOC (and POC, results not shown) showed only a small slope during algal and bacterial blooms (Figs. $5 \& 6$ ) while the slope is far steeper in between blooms and during winter (Fig. 4).

\section{Annual cycles of bacterial production and primary production}

Fig. 5 shows the annual cycles of bacterial production rate in the surface water at some stations in the Schelde estuary. At the marine stations ( 1 and 3 ) the annual cycle is characterized by 2 blooms, one in May and another in August-September. In the middle estuary, Stns 5 to 9, 2 more periods of increased bacterial production rate were recorded in March and in 


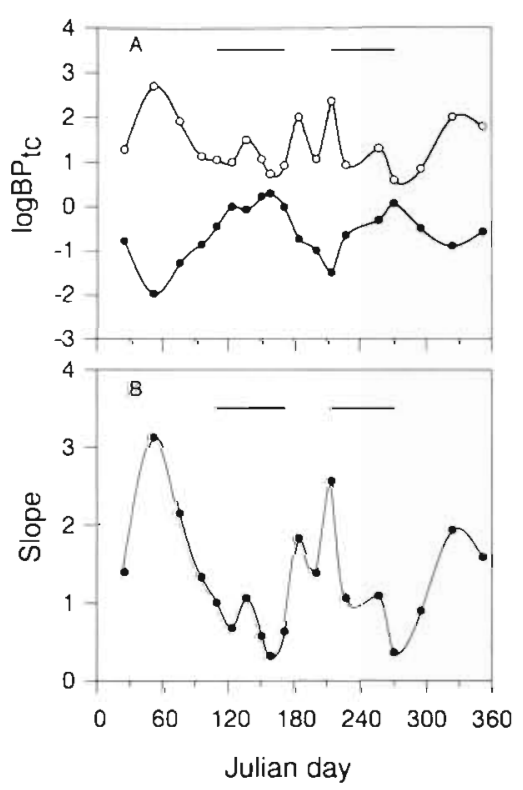

Fig. 4. Results of regression analysis of temperature-corrected bacterial production $\left(\mathrm{BP}_{\mathrm{tC}}\right)$ versus dissolved organic carbon (DOC) concentration along the salinity gradient in the Schelde estuary. (A) annual variation of $\mathrm{BP}_{\mathrm{tc}}$ calculated for each campaign by regression analysis, at a low DOC concentration which is representative of the lower estuary $(\bullet)$ and at a high DOC concentration which is representative of the upper estuary (o). The larger the difference between $\mathrm{BP}_{\mathrm{tr}}$ in the upper (0) and lower (•) estuary, the steeper the slope of the regression which is given in (B). Horizontal lines indicate periods of spring and summer bloom of phytoplankton and bacterioplankton (see Figs. 5 \& 6 )

November. As Fig. 5 shows, bacterial production rate in winter was below $0.5 \mu \mathrm{g} \mathrm{Cl}^{-1} \mathrm{~h}^{-1}$ in the marine and brackish part of the estuary up to $\operatorname{Stn} 7$. For all these stations maximum values during the spring bloom were $2.5 \mu \mathrm{g} \mathrm{Cl}^{-1} \mathrm{~h}^{-1}$. At stations with an annual average salinity $\leq 11.2$ psu (station numbers $\geq 9$ ) production rates in winter increased up to $5 \mu \mathrm{g} \mathrm{C}^{-1} \mathrm{~h}^{-1}$. During the whole year bacterial production rates were high and showed an irregular pattern of peaks.

To obtain a systematic comparison between bacterial production and primary production, both production rates were determined in subsamples of the same water sample. In Fig. 6, annual cycles of column production by both heterotrophic bacterioplankton and phytoplankton are given for some stations in the Schelde estuary. In winter, bacterial production rates were higher than primary production rates in the whole estuary. Generally, in the lower estuary, blooms of bacterioplankton seemed to be initiated after the start of phytoplankton blooms. This relation between bacterial production and primary production disappeared upstream of Sth 8 . The increase of bacterial production rates in the middle and upper estuary was so immense that during a substantial part of
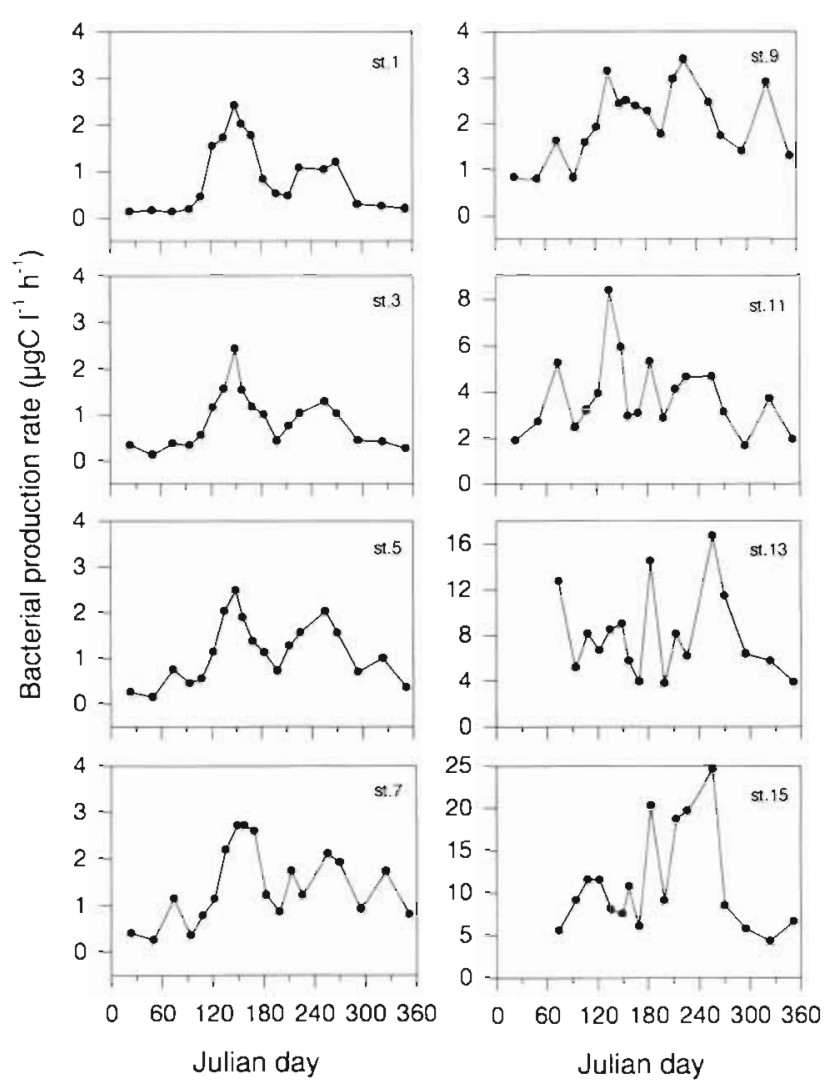

Fig. 5. Annual cycles of heterotrophic bacterial production rate at 8 stations in the Schelde estuary
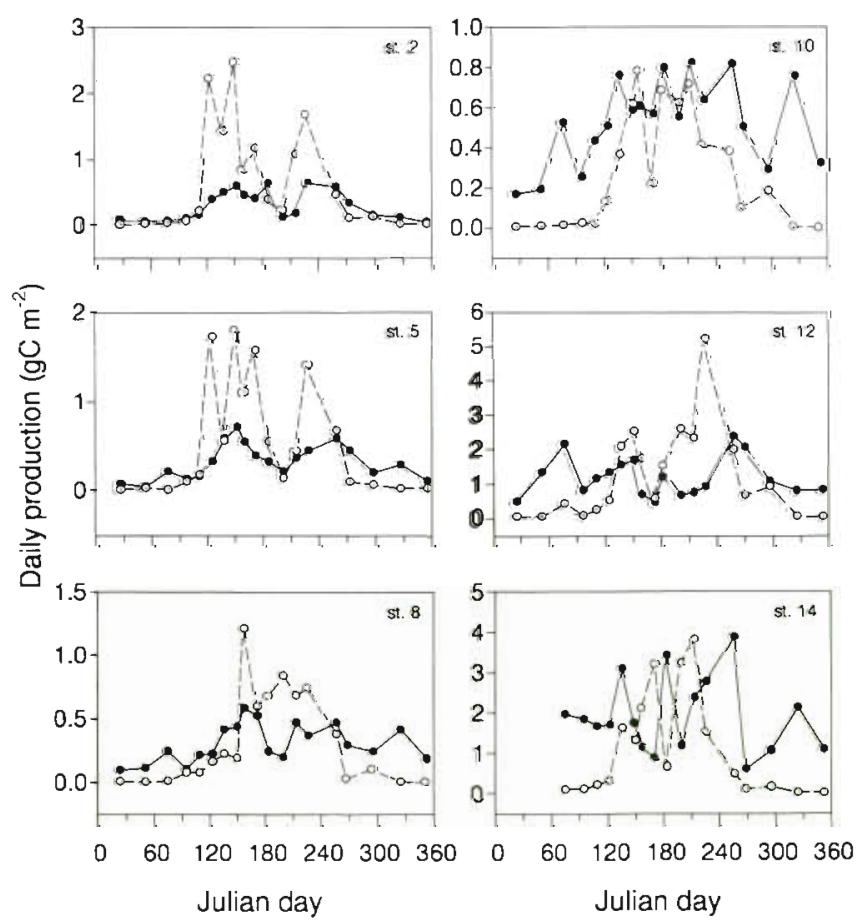

Fig. 6. Annual variation of daily column production of heterotrophic bacterioplankton $(\bullet)$ and phytoplankton $(0)$ at 6 stations in the Schelde estuary 
the year it was higher than the primary production rates.

Regression analysis of bacterial and primary production rate per station over the whole annual perlod showed a highly significant $\left(p<0.0001, r^{2}=0.56\right.$ to 0.74 ) correlation in the lower estuary, Stns 1 to 5. Goosen et al. (1995) showed in the Schelde estuary that bacterial production changed substantially during a tidal cycle and thus as a function of changing salinity. To eliminate the effect of varying salinities at each station in finding the most important factor regulating bacterial production rates, a forward stepwise multiple regression analysis was performed for data grouped in small ranges (2 psu) of salinity. Bacterial production rate was the dependent variable and primary production rate, DOC, POC and temperature the independent variables. The results of the regression analysis (Table 1) show that in the lower estuary, primary production rate was the mast important factor in explaining the variation in bacterial production rate while in the middle and upper estuary, temperature explained

Table 1. Stepwise multiple regression statistics with bacterial production ( $\mathrm{mg} \mathrm{C} \mathrm{m} \mathrm{Cm}^{-2} \mathrm{~d}^{-1}$ ) as dependent variable. All values except temperature $(\mathrm{T})$ were log-transformed. PP: gross primary production ( $\mathrm{mg} \mathrm{C} \mathrm{m} \mathrm{Cd}^{-2} \mathrm{~d}_{i} \mathrm{DOC}$ : dissolved organic carbon ( $\mathrm{mg} \mathrm{C} \mathrm{^{-1 }}$ ); POC: particulate organic carbon ( $\mathrm{mg} \mathrm{Cl}^{-1}$ ). In the column 'Sign factor' only the factors remaining in the resulting model to explain variation in bacterial production are given

\begin{tabular}{|c|c|c|c|c|}
\hline $\begin{array}{l}\text { Salinity range } \\
\text { (psu) }\end{array}$ & Sign factor & $\mathrm{p}$ & $r^{2}$ & $\mathrm{n}$ \\
\hline$<2$ & $P P$ & 0.006 & 0.224 & 32 \\
\hline $2-4$ & $\mathrm{POC}$ & 0.039 & 0.392 & 11 \\
\hline $4-6$ & $\mathrm{~T}$ & $<0.0001$ & 0.898 & 8 \\
\hline $6-8$ & $\mathrm{~T}$ & 0.014 & 0.504 & 11 \\
\hline $8-10$ & $\mathrm{~T}$ & $<0.0001$ & 0.685 & 13 \\
\hline $10-12$ & $\mathrm{~T}$ & $<0.0001$ & 0.695 & 17 \\
\hline $12-14$ & $\begin{array}{l}\mathrm{T} \\
\mathrm{POC}\end{array}$ & $\begin{array}{c}<0.0001 \\
0.075\end{array}$ & 0.808 & 13 \\
\hline $14-16$ & $T$ & 0.001 & 0.613 & 14 \\
\hline $16-18$ & $\begin{array}{l}\text { T } \\
\text { DOC } \\
\text { POC }\end{array}$ & $\begin{array}{l}0.006 \\
0.133 \\
0.004\end{array}$ & 0.96 & 9 \\
\hline $18-20$ & PP & 0.007 & 0.394 & 17 \\
\hline $20-22$ & $\begin{array}{l}\text { T } \\
\text { POC } \\
\text { PP }\end{array}$ & $\begin{array}{l}0.055 \\
0.075 \\
0.072\end{array}$ & 0.806 & 18 \\
\hline $22-24$ & $\begin{array}{l}\text { DOC } \\
\text { PP }\end{array}$ & $\begin{array}{c}0.118 \\
<0.0001\end{array}$ & 0.571 & 21 \\
\hline $24-26$ & $\begin{array}{l}\text { T } \\
\text { POC } \\
\text { PP }\end{array}$ & $\begin{array}{l}0.113 \\
0.031 \\
0.028\end{array}$ & 0.74 & 18 \\
\hline $26-28$ & PP & 0.002 & 0.431 & 19 \\
\hline $28-30$ & $\begin{array}{l}\text { DOC } \\
\text { POC } \\
\text { PP }\end{array}$ & $\begin{array}{c}0.048 \\
0.075 \\
<0.0001\end{array}$ & 0.804 & 15 \\
\hline$>30$ & PP & 0.003 & 0.686 & 10 \\
\hline
\end{tabular}

most of the variation in bacterial production rate. In most cases DOC and POC concentration were less important factors in explaining the variation in bacterial production.

\section{Bacterial growth rates}

At 4 stations, representative of the marine ( $\operatorname{Sin} 3$ ), the brackish (Stns 7 and 11) and the freshwater (Stn 15) parts of the estuary, standing stocks of bacteria were determined. At Stn 3 the variation in the bacterial concentrations in the water seemed to parallel the variation in bacterial production rates (Fig. 7). At the other 3 stations this relation between bacterial production and number was less clear. Unfortunately some important samples were missing at times when bacterial production rates showed maximum values. During the spring bloom an exceptionally high number of bacteria was recorded at Stn 7 (Baalhoek). Estimates of bacterial growth rates were obtained by dividing the production rate by the standing stock concentration. Growth rates were rather variable and no clear difference in growth rate between the different seasons could be calculated. Annual average $( \pm \mathrm{SD})$ growth rates $(\mu)$ for the Stns 3 ,

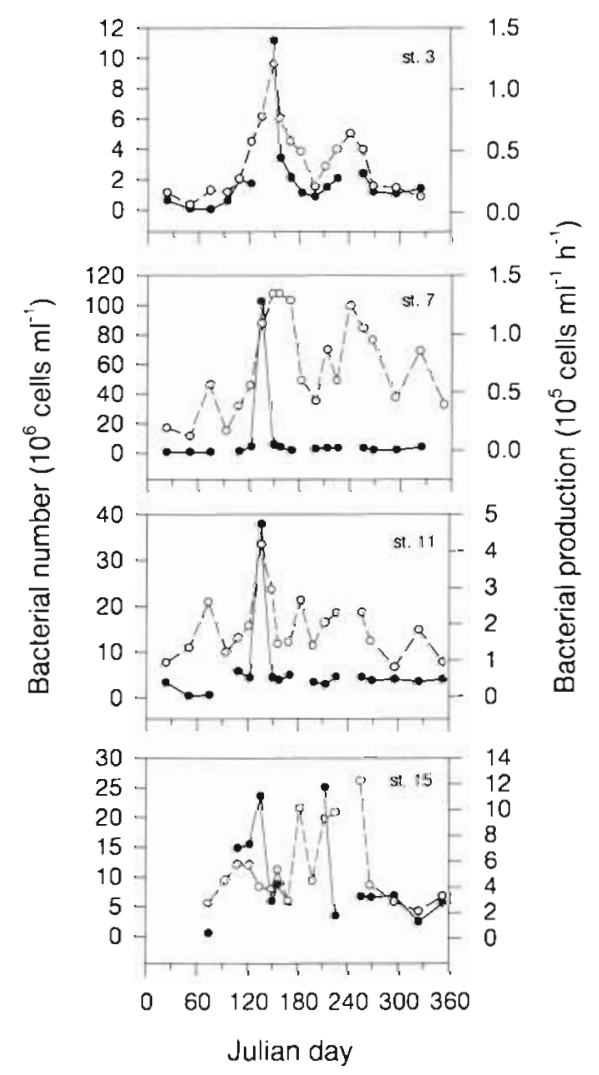

Fig. 7 Variation in bacterial numbers ( $)$ and production ( 0 ) at 4 representative stations in the Schelde estuary 
7,11 and 15 were $0.023 \pm 0.01,0.035 \pm 0.026,0.041 \pm$ 0.017 and $0.051 \pm 0.019 \mathrm{~h}^{-1}$ respectively, corresponding to generation times $\left(G=\ln 2 \mu^{-1}\right)$ of $30.5 \pm 12.8,19.9 \pm$ $15.1,16.7 \pm 7.0$ and $13.6 \pm 5.1 \mathrm{~h}$. Stepwise multiple regression analysis with specific growth rate as the dependent variable showed a very weak correlation with primary production $\left(p=0.071, r^{2}=0.215\right)$ at $\operatorname{Stn} 7$ and with temperature $\left(p=0.134, r^{2}=0.153\right)$ at Stn 3 . No significant relations were found at the other stations or with other variables.

\section{DISCUSSION}

\section{Bacterial abundance and production along the estuarine gradient}

For calculation of bacterial production rates from thymidine incorporation rates, conversion factors are needed. Combinations of different conversion factors may result in a wide range of production estimates (Ducklow \& Carlson 1992) It should be mentioned here that another combination of conversion factors would not have influenced the main results and conclusions of this study. As bacteria in the upper estuary are larger than in the lower estuary (Goosen et al. 1995) the use of 1 carbon conversion factor for the whole estuary may probably underestimate the differences between the upper and lower estuary.

Bacterial abundance and production in the Schelde estuary showed a typical longitudinal profile during the whole year with low abundances and production rates in the lower estuary and higher abundances and production rates upstream. Production rates mainly increased from the middle to the upper estuary, up to values 10 times higher than in the lower estuary. Bacterial numbers in the Schelde estuary were comparable to numbers found in other estuaries but were at the high range in the upper estuary (see also Heip et al. 1995). Maximum bacterial concentrations are in the range of the maximum concentrations given for Chesapeake Bay (USA) (Ducklow \& Shiah 1993). Bacterial production rates in the lower Schelde estuary were comparable to other estuaries, whereas those in the upper estuary were among the highest reported in the literature (see Ducklow \& Shiah 1993, Heip et al. 1995). Goosen et al. (1995) compared bacterial production rates during spring in European estuaries and found production rates in the maximum turbidity zone and the freshwater part of the Schelde estuary to be very high. As in the Loire estuary (France) (Relexans et al. 1988) bacterial production rates increased in the turbidity zone. Relexans et al. (1988) explained the increased heterotrophic activity by accumulation of phytoplankton material and, as in the Schelde estuary, found a good correlation between bacterial productivity and POC concentration. The gradient of organic carbon concentration explained most of the variation in bacterial production over the longitudinal transect in the Schelde estuary while temperature only had a marginal effect (Figs. $3 \& 4$ ). The severe oxygen depletion in the turbidity zone in the Loire estuary was mainly restricted to the summer when the temperature was high. In the Schelde estuary the oxygen depletion was present during all seasons, and along the salinity gradient correlated with bacterial production rates.

\section{Annual variation of bacterial production rates}

The results of this study show that during an annual cycle in the lower Schelde estuary bacterial production is significantly correlated to an autochthonous source of organic carbon, namely phytoplankton primary production. Bacterial production was low in winter and did not increase until the start of the phytoplankton spring bloom. Bacterial production rate seemed to be coupled to phytoplankton primary production rate. This statement is validated by statistical analysis (Table 1) which showed primary production to be the most important factor explaining the variation of bacterial production in the lower estuary.

In the middle and upper estuary bacterial production rates were relatively high during the whole year. No correlation between bacterial production rate and primary production rate was observed and the variations in bacterial production could mainly be explained by the temperature. The small or nonexistent response of bacteria to primary production in the middle and upper estuary may be explained by the presence of organic matter of allochthonous origin leading to permanent, high, non-limiting concentrations of DOC and POC. The amount of rarhon added by phytoplankton exudates must have been relatively small. Also nutrients were present in non-limiting concentrations (Kromkamp et al. 1995) leaving temperature as the major regulating factor for bacterial growth.

The relatively larger response of bacteria to primary production in the lower estuary explains the decreased slope of the regression between bacterial production and organic carbon along the salinity gradient during phytoplankton blooms (Fig. 4). During the spring and summer bloom, phytoplankton cells release labile organic material. In the lower estuary this fresh material is the major carbon source leading to a bloom of heterotrophic bacteria. Consequently the gradient in bacterial production rate between upper and lower estuary will decrease then. Rapid decomposition of fresh DOC may explain why, despite the phytoplankton bloom, no increased con- 
centrations of DOC and no correlation of DOC with bacterial production was found during the annual cycle in the Schelde estuary.

\section{Heterotrophy versus autotrophy}

In Table 2 our estimates of the annual bacterial production (gross production: $\mathrm{BP}_{\mathrm{g}}$, net production: $\mathrm{BP}_{\mathrm{n}}$ ) in the Schelde estuary are compared with estimates of the annual gross $\left(\mathrm{PP}_{\mathrm{q}}\right)$ and net $\left(\mathrm{PP}_{\mathrm{n}}\right)$ primary production (based on $2 \mathrm{~h}$ incubations with ${ }^{14} \mathrm{C}$-bicarbonate; Kromkamp \& Peene 1995a). The $\mathrm{BP}_{\mathrm{n}}: \mathrm{PP}_{\mathrm{n}}$ ratios are very high compared to the expected 10 to $50 \%$ for pristine systems (Hagström et al. 1979, Azam et al. 1983). The high ratios found in the Schelde estuary are in agreement with the results of Soetaert et al. (1994) and Kromkamp \& Peene (1995a, b), who concluded that net phytoplankton primary production seems not to be possible in a large area of the middle and upper Schelde estuary. The thymidine method measures net bacterial production. When we take into account respiration by assuming a $30 \%$ growth efficiency for bacteria, the total amount of carbon processes by bacteria $\left(\mathrm{BP}_{\mathrm{g}}\right)$ will be higher by even more than a factor of 3 (Table 2). Consequently, comparison of gross bacterial production with net primary production would result in extremely high ratios of BP:PP especially for the upper Schelde estuary. On an annual scale, in the whole estuary the amount of carbon processed by heterotrophic bacteria is higher than the carbon input by phytoplankton primary production. A factor which may have an effect on the ratios we found is primary production by microphytobenthos. The incidental measurements on microphytobenthos in the Schelde estuary showed that microphytobenthos production can be significant compared to phytoplankton primary production (Kromkamp et al. 1995). Possibly primary production by microphytobenthos provides an extra carbon source for planktonic heterotrophic bacteria.

The ratio bacterial production:primary production (BP:PP) can be considered as an indication of the trophic state of a system. Our results show that the Schelde estuary is a heterotrophic system and that the heterotrophy is increasing from the lower to the upper estuary. By modelling all autotrophic and heterotrophic processes, Soetaert \& Herman (1995b) came to the same conclusion about the trophic state of the Schelde estuary. Measurement of $\mathrm{CO}_{2}$ fluxes (Frankignoulle et al. 1996) also demonstrated the heterotrophy of the system.
In the upper Schelde estuary, the annual variations in bacterial and primary production rates were not correlated with each other As in the Schelde estuary, a high BP:PP ratio and a weak or nonexistent correlation between bacteria and phytoplankton has also been found in other heterotrophic systems like the Delaware estuary (Hoch \& Kirchman 1993), the upper St. Lawrence estuary (Painchaud \& Therriault 1989), the Hudson river (Findlay et al. 1991) and the Rhône river plume (Kirchman et al. 1989). In the lower Schelde estuary, bacterial production rates were correlated with primary production rates. A positive correlation between bacterial and phytoplankton biomass and/or production has been observed mainly in autotrophic systems (Bird \& Kalff 1984, Lancelot \& Billen 1984, Cole et all 1988. Currie 1990, Simnn et al. 1992). In the heterotrophic lower Schelde estuary, BP and PP were correlated despite the fact that BP exceeded PP for long periods. This may be explained by the algal blooms which probably produce enough labile DOC to increase bacterial production. In this way phytoplankton may regulate the temporal variation in bacterial production rate above the production rate that thrives on allochthonous carbon. This allochthonous organic carbon enters the upper estuary and is degraded while being transported to the lower estuary (Fig. 3). As a consequence the allochthonous material entering the lower estuary is probably rather refractive. However, no direct measurements on degradability of dissolved organic matter along the salinity gradient in the Schelde estuary have been performed.

Table 2. Comparison of annual net $\left(\mathrm{BP}_{\mathrm{n}}\right)$ and gross $\left(\mathrm{BP}_{\mathrm{g}}\right)$ production $(\mathrm{g} \mathrm{C}$ $m^{-2} \mathrm{yr}^{-1}$ ) by heterotrophic bacterioplankton and annual gross $\left(\mathrm{PP}_{\mathrm{g}}\right)$ and net

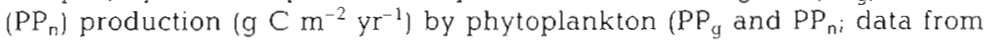
Kromkamp \& Peene 1995b) in the Schelde estuary in 1991. BP ${ }_{y}$ was calculated from $\mathrm{BP}_{n}$ assuming a $30 \%$ growth efficiency. nd: not determined

\begin{tabular}{|c|c|c|c|c|c|c|c|}
\hline Stn & $\begin{array}{l}\text { Annual average } \\
\text { salinity (psu) }\end{array}$ & $P P_{g}$ & $\mathrm{PP}_{\mathrm{n}}$ & $\mathrm{BP}_{\mathrm{n}}$ & $\mathrm{BP}_{9}$ & \multicolumn{2}{|c|}{$\begin{array}{c}\text { Ratio } \\
\mathrm{BP}_{\mathrm{n}} / \mathrm{PP}_{\mathrm{n}} \mathrm{BP}_{\mathrm{g}} / \mathrm{PP}_{\mathrm{n}}\end{array}$} \\
\hline 1 & 29.2 & 265 & 194 & 80 & 267 & 0.41 & 1.38 \\
\hline 2 & 25.7 & 181 & 125 & 92 & 307 & 0.74 & 2.46 \\
\hline 3 & 23.9 & 228 & 168 & 62 & 207 & 0.37 & 1.23 \\
\hline 4 & 24 & 169 & 122 & 67 & 223 & 0.55 & 1.83 \\
\hline 5 & 21.9 & 265 & 195 & 101 & 336 & 0.52 & 1.72 \\
\hline 6 & 21.5 & 146 & 104 & 114 & 380 & 1.10 & 3.65 \\
\hline 7 & 17.9 & 146 & 106 & 75 & 250 & 0.71 & 2.36 \\
\hline 8 & 145 & 91 & 60 & 103 & 343 & 1.72 & 5.72 \\
\hline 9 & 11.2 & 70 & 40 & 145 & 483 & 3.63 & 12.08 \\
\hline 10 & 9.7 & 79 & 43 & 180 & 600 & 4.19 & 13.95 \\
\hline 11 & 6.1 & 139 & 65 & 294 & 980 & 4.52 & 15.08 \\
\hline 12 & 2.6 & 280 & 149 & 411 & 1370 & 2.76 & 9.19 \\
\hline 13 & 1.2 & 475 & 288 & 724 & 241.3 & 2.51 & 8.38 \\
\hline 14 & 1 & 273 & nd & 667 & 2223 & - & - \\
\hline 15 & 0.8 & 277 & nd & 767 & 2556 & - & - \\
\hline
\end{tabular}


Acknowledgements. We thank the crew of the RV 'Luctor' for assistance in sampling and the staff of the 'waterlab' and the 'bodemlab' for DOC and POC analyses. Indispensable help in statıstıcal analyses was given by Dr P. M. J. Herman. In addıtion, we thank the referees for thelr useful comments, which helped to improve the manuscript. This is publication no. 2203 of the NIOO-CEMO.

\section{LITERATURE CITED}

Azam F, Fenchel T, Field JG, Gray JS, Meyer-Reil LA, Thingstad F (1983) The ecological role of water-column microbes in the sea. Mar Ecol Prog Ser 10:257-263

Billen G, Lancelot C, De Becker E. Servais P (1988) Modelling microbial processes (phyto-and bacterioplankton) in the Schelde estuary. Hydrobiol Bull 22:43-55

Bird DF, Kalff J (1984) Empirical relationships between bacterial abundance and chlorophyll concentration in fresh and marine waters. Can J Fish Aquat Sci 41:1015-1023

Cole JJ, Findlay S, Pace ML (1988) Bacterial production in fresh and saltwater ecosystems: a cross-system overview. Mar Ecol Prog Ser 43:1-10

Currie DJ (1990) Large-scale variability and interactions among phytoplankton, bacterioplankton, and phosphorus. Limnol Oceanogr 35:1437-1455

Ducklow HW, Carlson CA (1992) Oceanic bacterial production. In: Marshall KC (ed) Advances in microbial ecology. Vol 12. Plenum Piess, New York, p 113-181

Ducklow HW, Shiah FK (1993) Bacterial production in estuaries. In: Ford TE (ed) Aquatic microbiology an ecological approach. Blackwell Scientific Publications, Oxford, p 261-287

Eilers P, Peeters JCH (1988) A model for the relationship between light intensity and the rate of photosynthesis in phytoplankton. Ecol Model 42:199-215

Ellenbroek FM, Cappenberg TE (1991) DNA synthesis and tritiated thymidine incorporation by heterotrophic freshwater bacteria in continuous culture. Appl Environ Microbiol 57:1675-1682

Findlay S, Pace ML, Lints D, Cole JJ, Caraco NF, Peierls B (1991) Weak coupling of bacterial and algal production in a heterotrophic ecosystem: the Hudson River estuary. Limnol Oceanogr 36:268-278

Frankignoulle M, Bourge I, Wollast R (1996) Atmospheric $\mathrm{CO}_{2}$ fluxes in a highly polluted estuary (the Scheldt). Limnol Oceanogr 41:365-36y

Fuhrman JA, Azam F (1982) Thymidine incorporation as a measure of heterotrophic bacterioplankton production in marine surface waters: evaluation and field results. Mar Biol 66:109-120

Goosen NK, Rijswijk P van, Brockmann U (1995) Comparison of heterotrophic bacterial production rates in early spring in the turbid estuaries of the Scheldt and the Elbe. Hydrobiologia 311:31-42

Hagström $\AA$, Larsson U, Hörsted P, Normark S (1979) Frequency of dividing cells, a new approach to the determination of bacterial growth rates in aquatic environments. Appl Environ Microbiol 37:805-812

Heip C (1989) The ecology of the estuaries of Rhine, Meuse and Scheldt in the Netherlands. In: Ros JD (ed) Topics in marine biology. Scientia Mar 53:457-463

Heip CHR, Goosen NK, Herman PMJ, Kromkamp J, Middelburg JJ, Soetaert K (1995) Production and consumption of biological particles in temperate tidal estuaries. In: Ansell AD, Gibson RN, Barnes M (eds) Oceanogr Mar Biol Annu Rev 33:1-149
Hoch MP, Kirchman DL (1993) Seasonal and inter-annual variability in bacterial production and biomass in a temperate estuary. Mar Ecol Prog Ser 98:283-295

Kirchman DL, Soto Y, Van Wambeck F, Bianchı M (1989) Bacterial production in the Rhone River plume: effect of mixing on relationships among microbial assemblages. Mar Ecol Prog Ser 53:267-275

Kromkamp J, Peene J (1995a) Possibility of net phytoplankton primary production in the turbid Schelde Estuary (SW Netherlands). Mar Ecol Prog Ser 121:249-259

Kromkamp J, Peene J (1995b) On the net growth of phytoplankton in two Dutch estuaries. Water Sci Technol 32:55-58

Kromkamp J, Peene J, Rijswijk. P van, Sandee A, Goosen N (1995) Nutrients, light and primary production by phytoplankton and microphytobenthos in the eutrophic, turbid Westerschelde estuary (The Netherlands). Hydrobiologia 311:9-19

Lancelot C, Billen G (1984) Activity of heterotrophic bacteria and its coupling to primary production during the spring phytoplankton bloom in the southern bight of the North Sea. Limnol Oceanogr 29:721-730

Larsson U, Hagström $\AA$ (1982) Fractionated phytoplankton primary production, exudate release and bacterial production in a Baltic eutrophication gradient. Mar Biol 67 : $57-70$

Lee S, Fuhrman JA (1987) Relationships between biovolume and biomass of naturally derived marine bacterioplankton. Appl Environ Microbiol 53:1298-1303

Nieuwenhuize J, Maas YEM, Middelburg JJ (1994) Rapid analysis of organic carbon and nitrogen in particulate materials. Mar Chem 45:217-224

Painchaud J. Therriault JC (1989) Relationships between bacteria, phytoplankton and particular organic carbon in the upper St. Lawrence estuary. Mar Ecol Prog Ser 56: $301-311$

Pomeroy LR (1974) The ocean's food web, a changing paradigm. BioSci 24:499-504

Porter KG, Feig YS (1980) The use of DAPI for identifying and counting aquatic microflora. Limnol Oceanogr 25: 943-948

Relexans JC, Meybeck M, Billen G, Brugeaille M, Etcheber $H$, Somville $M$ (1988) Algal and microbial processes involved in particulate organic matter dynamics in the Loire estuary. Estuar Coast Shelf Sci 27:625-644

Shiah FK, Ducklow HW (1994a) Temperature and substrate regulation of bacterial abundance, production and specific growth rate in Chesapeake Bay, USA. Mar Ecol Prog Ser 103:297-308

Shiah FK, Ducklow HW (1994b) Temperature regulation of heterotrophic bacterioplankton abundance, production, and specific growth rate in Chesapeake Bay. Limnol Oceanogr 39:1243-1258

Shiah FK, Ducklow HW (1995) Multiscale variability in bacterioplankton abundance, production, and specific growth rate in a temperate salt-marsh tidal creek. Limnol Oceanogr 40:55-66

Simon M, Cho BC, Azam F (1992) Significance of bacterial biomass in lakes and the ocean: comparison to phytoplankton biomass and biogeochemical implications. Mar Ecol Prog Ser 86:103-110

Smits JD, Riemann B (1988) Calculation of cell production from [ ${ }^{3} \mathrm{H}$ |thymidine incorporation with freshwater bacteria. Appl Environ Microbiol 54:2213-2219

Soetaert K, Herman PMJ (1995a) Nitrogen dynamics in the Westerschelde estuary (SW Netherlands) estimated by means of the ecosystem model MOSES. Hydrobiologia $311: 225-246$ 
Soetaert K, Herman PMJ (1995b) Carbon flows in the Westerschelde estuary (The Netherlands) evaluated by means of an ecosystem model (MOSES). Hydrabiologia 311: $247-266$

Soetaert K, Herman PMJ, Kromkamp J (1994) Living in the twilight: estimating net phytoplankton growth in the Westerschelde estuary (the Netherlands) by means of a global ecosystem model (MOSES). J Plankton Res 16: $1277-1302$

Van Spaendonk JCM, Kromkamp JC, de Visscher PRM (1993) Primary production of phytoplankton in a turbid coastal

Responsible Subject Editor: J. Fuhrman, Los Angeles, California, USA plain estuary, the Westerschelde (The Netherlands). Neth J Sea Res 31:267-279

Vegter F, de Visscher PRM (1984) Phytoplankton primary productıon in brackish lake Grevelingen (SW Netherlands) during 1976-1981. Neth J Sea Res 18:246-259

White PA, Kalff J, Rasmussen JB, Gasol JM (1991) The effect of temperature and algal biomass on bacterial production and specific growth rate in freshwater and marine habitats. Microb Ecol 21:99-118

Wilkinson L (1989) SYSTAT: the system for statistics. SYSTAT, Evanston, IL

Manuscript first received: August 10, 1996

Revised version accepted: January 28, 1997 